\title{
Food granulation as a sustainable and survival means
}

\section{La granulación de alimentos como medio sustentable y de supervivencia}

\author{
SALGADO-LOYO, Eduardo $\dagger$, CRUZ-GÓMEZ, Marco Antonio*, MEJÍA-PÉREZ, José Alfredo and \\ FLORES-MARTÍNEZ, Guillermo
}

\begin{abstract}
Benemérita Universidad Autónoma de Puebla; Faculty of Engineering, Tribology and Transportation Group, Academic Body 189 (Disaster Prevention and Sustainable Development, Tribology, BUAP), Graduate Building, First Level, Cubicle No. 16, Blvd. Valsequillo esq. Av. San Claudio, Ciudad Universitaria, Col. San Manuel, CP. 72570, Puebla Mexico.
\end{abstract}

ID 1 $1^{\text {st }}$ Author: Eduardo, Salgado-Loyo / ORC ID: 0000-0001-5418-4907, Researcher ID Thomson: AAP-2962-2020, CVU CONACYT ID: 1019384

ID $1^{\text {st }}$ Coauthor: Marco Antonio, Cruz-Gómez / ORC ID: 0000-0003-1091-8133, Researcher ID Thomson: S-3098-2018, CVU CONACYT ID: 349626

ID $2^{\text {nd }}$ Coauthor: José Alfredo, Mejía-Pérez / ORC ID: 0000-0002-4090-8828, Researcher ID Thomson: G-3354-2019

ID $3^{\text {rd }}$ Coauthor: Guillermo, Flores-Martinez / ORC ID: 0000-0002-2243-2379, Researcher ID Thomson: G-3384-2019, CVU CONACYT ID: 169853

DOI: $10.35429 / J A N R E .2020 .6 .4 .7 .13$

Received: January 15, 2020; Accepted: June 30, 2020

\begin{abstract}
The consumption of avocado is of great importance in the daily diet of the human being, since this fruit contains high levels of Omega 3 and various vitamins (B6, B9 and E) and minerals (magnesium, iron, zinc and phosphorus). Today, Mexico is one of the main avocado producers worldwide. However, the high demand and the low production of this fruit makes the price of avocado more expensive and, therefore, the Mexican population reduces its consumption and seeks nutritional alternatives. For this reason, this research aimed to propose the manufacture of solid avocado tablets (based on pharmaceutical techniques) by granulating and compacting the dehydrated powder of this fruit. This was carried out under a mixed approach by applying quantitative and qualitative technologies to systematic, critical and empirical processes in order to choose the best granulation technique, the ideal binder and the type of compaction to use to achieve solid tablets using dehydrated avocado powder. This tablet aims to preserve the same nutrients as natural avocado and reach all sectors of the population to generate a sustainable and human survival environment.
\end{abstract}

Food dehydration, Granulation, Binder

\begin{abstract}
Resumen
El consumo de aguacate es de gran importancia en la dieta diaria del ser humano, ya que esta fruta contiene niveles altos de Omega 3 y diversas vitaminas (B6, B9 y E) y minerales (magnesio, hierro, zinc y fósforo). Hoy en día, México es uno de los principales productores de aguacate a nivel mundial. Sin embargo, la alta demanda y la escasa producción de esta fruta provoca que el precio del aguacate sea más caro y, por ende, la población mexicana reduce el consumo de este y busca alternativas nutricionales. Por tal motivo, esta investigación tuvo como objetivo proponer la fabricación de pastillas sólidas de aguacate (con base en técnicas farmacéuticas) mediante la granulación y compactación del polvo deshidratado de esta fruta. Esta fue realizada bajo un enfoque mixto al aplicar tecnologías cuantitativas y cualitativas a procesos sistemáticos, críticos y empíricos con la finalidad de escoger la mejor técnica de granulación, el aglutinante ideal y el tipo de compactación a utilizar para lograr pastillas sólidas mediante polvo deshidratado de aguacate. Esta pastilla pretende conservar los mismos nutrientes que el aguacate natural y llegar a todos los sectores de la población para generar un medio sustentable y de supervivencia humana.
\end{abstract}

Deshidratación de alimentos, Granulación, Aglutinante

Citation: SALGADO-LOYO, Eduardo, CRUZ-GÓMEZ, Marco Antonio, MEJÍA-PÉREZ, José Alfredo and FLORESMARTÍNEZ, Guillermo. Food granulation as a sustainable and survival means. Journal-Agrarian and Natural Resource Economics. 2020. 4-6:7-13.

\footnotetext{
* Correspondence to the Author: (Email: imartinezca@uaemex.mx).

$\dagger$ Researcher contributed as first author.
} 


\section{Introducction}

A study by the UN revealed that more than 820 million people usually go to bed hungry in the world, therefore, the sustainability of the food system must be a primary objective worldwide. Likewise, it is necessary to effect a profound change in the international agri-food system, since approximately 1,300 million tons of food (produced for human consumption) is wasted or lost. United Nations [UN]. (s.f.) and Sustainability. (s.f.).

Today, Mexico is one of the main avocado producers worldwide. However, and according to statistical data published by PROFECO, in the month of July there is a considerable increase in the price of this fruit in the country, due to high demand and low production due to climatic changes, worker strikes, etc. Therefore, the production of dehydrated avocado powder could be an economical solution when the production of this fruit is lower in the country. Since, the dehydration of the avocado prevents the oxidation of fats, the decomposition of the compounds and, therefore, does not lose its main nutritional properties. Barría, C. (2019), PROFECO (2019) and Ramos Solís, R. (2006).

\begin{tabular}{|c|c|}
\hline Year & $\begin{array}{c}\text { Avocado price to the consumer in Mexico } \\
\text { (in pesos) }\end{array}$ \\
\hline 2012 & $39( \pm 2)$ \\
\hline 2013 & $45( \pm 2)$ \\
\hline 2014 & $43( \pm 2)$ \\
\hline 2015 & $40( \pm 2)$ \\
\hline 2016 & $57( \pm 2)$ \\
\hline 2017 & $72( \pm 2)$ \\
\hline 2018 & $57( \pm 2)$ \\
\hline 2019 & $75( \pm 2)$ \\
\hline
\end{tabular}

Table 1 Price of avocado to the consumer in Mexico during the month of July 2012-2019

Source: PROFECO, (2019)

However, this product would present economic losses for its manufacturers, because they must turn to nutrition experts to indicate the ideal amount of avocado powder to consume per meal. Likewise, the powdered avocado could present losses in its packaging. For these reasons, an alternative to solve these problems could be the manufacture of solid avocado tablets by granulating and compacting the dehydrated powder of this fruit based on the pharmaceutical techniques used in the manufacture of solid oral dosage forms.
This alternative could be carried out by substituting the powder of the active ingredient of the drug for the dehydrated avocado powder during the pharmaceutical granulation process. However, in order to achieve successful avocado tablets, the moisture percentage of the dehydrated avocado powder, the speed of binder addition during granulation, binder viscosity, levels of use of the binder in granulation, the different techniques to obtain granules must be considered. and the compaction of granules to generate solid tablets of oral dose.

\section{Methodology}

This research has a mixed approach which applies quantitative and qualitative technologies to systematic, critical and empirical processes. The application of the quantitative method was necessary for the analysis of cause and effect in sequential processes in order to predict a hypothesis. To control this research, descriptive, correlational and explanatory fields must be combined taking into account the environment of the phenomenon, in such a way that there is a correlation between variables for easy understanding. It should be noted that this research requires a non-experimental study, since the changes over a certain time were analyzed by observing the phenomenon in its natural context. For this reason, it was necessary to apply the qualitative method, since it allows to deepen about the phenomena related to the problem, proposing possible results of the data obtained under an inductive process; contextualizing the topic with the use of primary research sources such as: written materials (books, newspaper articles, notes), as well as web pages. Hernández, 2010, p.275.

\section{Methodology used to obtain avocado powder}

\section{Dehydration of avocado paste}

Previous studies determined that avocado powder and natural avocado have almost the same nutritional contribution (Omega 3, vitamins $\mathrm{B} 6, \mathrm{~B} 9$ and $\mathrm{E}$ and the minerals magnesium, iron, zinc and phosphorus), because the biomolecules present are almost in the same proportions. This can be confirmed by using the following methodologies. Avocado calories: energy value in $100 \mathrm{~g}$ and nutritional sheet. (May 21, 2019) and Ramos Solís, R. (2006). 
First, a ripe avocado must be selected without any type of plague in order not to affect its sensory characteristics. Subsequently, the pit and peel are separated from the avocado pulp. In the next step, the avocado pulp milling is done to increase the mass and heat transfer area of the avocado pulp to obtain a paste of $904 \mathrm{~g} / \mathrm{cm}^{3}$. The paste obtained from grinding is placed in the dehydrator containers, taking care that the paste does not exceed $2 \mathrm{~cm}$ in thickness. Ramos Solís, R. (2006).

By following the steps above, the pasta must go through a cooling process before dehydration. At this stage, a refrigeration chamber $\left(1-5^{\circ} \mathrm{C}\right)$ should be used for at least one hour to achieve adequate cooling. When the product is in contact with cold air it releases energy to the surrounding environment and thus this leads to a temperature gradient causing a conductive heat transfer from the core to the surface and a phase change (crystallization of water). On the other hand, on the surface of the product there is a transfer of water between the product and its surroundings, because the concentration of water vapor in the surrounding air is less than the concentration of water vapor in the air in equilibrium. Therefore, the cooling process limits the development of microorganisms and prevents oxidation of the avocado paste by lowering its temperature below its freezing point. Mulot, V., Benkhelifa, H., Pathier, D., Ndoye, F.-T., \& Flick, D. (2019) and Ramos Solís, R. (2006).

Lastly, the containers containing the avocado paste are dehydrated in a freeze dryer (under the sublimation principle). Drying by freeze drying is used in foods that spoil or undergo changes in their structure due to the high temperatures used in conventional drying methods. For this experimentation, the drying time of the avocado paste was in different time intervals $(2-10 \mathrm{~h})$. Among the parameters to control in dehydration, the pressure in the vacuum chamber of the lyophilizer must be less than atmospheric (between $450 \times 10^{-3}$ and 50x $10^{-}$ ${ }^{3}$ mbar) and the minimum temperature of the freeze-dryer condenser should be $-40^{\circ} \mathrm{C}$. Ramos Solís, R. (2006).

\section{Analysis of the pharmaceutical techniques for obtaining avocado granules}

\section{Granulation process}

Wet granulation is the most widely used technique in the pharmaceutical industry, because it enables the use of little fluid, less compressibility and, therefore, elegant, safe and effective pharmaceutical products such as tablets and capsules are achieved. This technique is developed in three stages: wetting-nucleation, growth-consolidation and wear-breakage. During wetting, binder liquid is added to the powder mixture. Nucleation begins with the formation of small granules. During these stages, the binder spreads by capillary action and the growth of the granules is dependent on viscous forces. Excellent wetting and nucleation depend on various parameters, for example, the nature, amount and properties (viscosity, density, wettability, solid-liquid contact angle) of the binder. Likewise, the growth of the granules is influenced by the degree of saturation of the pores with the binder. In the same way, the coalescence and consolidation step represent the growth and densification of granules due to collisions and, therefore, this step influences the porosity of the granules. Lastly, the wear and tear step occur when the granules break due to impact, wear or compaction in the granulator.

On the other hand, among the different wet granulation techniques, the ones commonly carried out in the industry are "HSWG" high shear granulation, "FBG" fluidized bed granulation and "TSG" twin screw granulation. Arndt, O. et al. (2018), Dürig, T., \& Karan, K. (2019), Suresh, P., Sreedhar, I., Vaidhiswaran, R., \& Venugopal, A. (2017) and Thapa, P., Tripathi, J ., \& Jeong, SH (2019).

\section{High cut granulation "HSWG"}

HSWG is one of the most widely used techniques in the pharmaceutical industry because its process is short in time, presents denser granules, requires less binder compared to other techniques, etc. Furthermore, several types of excipients are compatible with this technique. 
However, this granulation technique has some disadvantages, for example, the mechanical degradation of brittle particles, the chemical degradation of materials sensitive to high temperatures and the possible formation of lumps due to excess humidity. In the same way, this technique presents several critical parameters that have a great relevance in the physical and mechanical properties of the final granules. Suresh, P. et al. (2017) and Thapa, P., Tripathi, J., \& Jeong, S. H. (2019).

\section{Twin screw granulation "TSG"}

TSG is a continuous technique that involves kneading the powder mixture using two interlocking co-rotating screws encased in a barrel with powder and liquid injection ports. The powder mixture and granulation liquid is conveyed along the screw to achieve granulation. This process is good for heat sensitive materials and the yield percentage of its granules is $98 \%$. This technique presents a higher load of the active principle of the drug and, therefore, enables the efficient mixing of the starting materials, the distribution of the binder solution during the wetting phase and the densification of the granules formed. However, any variation in screw length, geometry and diameter can affect the properties of the granules and thus the properties of the tablet. Suresh, P. et al (2017), Thapa, P., Tripathi, J., \& Jeong, S. H. (2019) and Wang, L. G. et al (2020).

\section{Fluidized bed granulation "FBG"}

This technique consists of a nozzle, a solution delivery system, and compressed air to atomize the liquid binder. In the FBG, a distributor plate allows to retain the dust in the container, while the filters (at the top of the column) allow the air to pass through and, on the other hand, these filters prevent the solid particles from escaping. After the powder is fluidized, the binder solution is sprayed (via spray nozzles) onto the fluidized bed to begin agglomeration of granules. Finally, the granules are dried by blowing air through the system. In FBG, the agglomeration rate is guided by operating parameters, for example, spray speed, fluidization speed, nozzle position, and atomizing air pressure. In the same way, this technique is suitable in heat sensitive materials and the percentage of yield of its granules is $99 \%$. On the other hand, this process requires little energy to dry large surfaces.
However, FBG requires more liquid solution during the process which generates highly porous granules. Arndt, O. et al. (2018), Askarishahi, M. et al. (2019), Suresh, P. et al. (2017) and Thapa, P., Tripathi, J., \& Jeong, S. H. (2019).

\section{Parameters of the most common binders in wet granulation}

In wet granulation, the suitable binder must possess adequate surface wetting capacity in order to ensure optimum adhesion and cohesion between interparticulate surfaces in the wet state. Therefore, the ideal binder produces dense, uniform granules with low friability and a high degree of compactness.

In the pharmaceutical industry, hydroxypropylcellulose "HPC", methylcellulose "MC", ethylcellulose "EC", povidone "PVP" and partially gelatinized starch "PGS" are the most used binders. On the one hand, HPC is used with water, hydroalcoholic solvents, and polar organic solvents. The typical use level of this binder is $2-6 \%$ and it exhibits $2 \%$ viscosity 5,8 and $12 \mathrm{cps}$ (respectively). On the other hand, MC is used with water or hydroalcoholic solvents. Typical use level for this binder is 2-10\% and has a $2 \%$ viscosity $15 \mathrm{cps}$. Likewise, $\mathrm{EC}$ is used with polar and non-polar organic solvents, not soluble if the water exceeds $20 \%$ of the total solvent. The typical use level of this binder is $2-10 \%$ and it exhibits $5 \%$ viscosity $4,7,10,14$ and 22 cps (respectively). Similarly, PVP is used with water, hydroalcoholic solvents, and polar organic solvents. Typical use level for this binder is $2-10 \%$ and it exhibits $5 \%$ viscosity 2 , 2.5 , and 55 cps (respectively). Lastly, PGS can be used with water only, it also acts as a disintegrant, effective use levels are mostly higher than other binders and the typical use level for this binder is 2-15\%. Dürig, T., \& Karan, K. (2019) and Yeager, J. et al. (2011).

\section{Transformation of granules into avocado pills using a tablet press}

Granule compression (using a Natoli BLP-16 rotary tablet press) is a process performed by punch filling, metering, pre-compression, main compression, tablet ejection, and bottom punch removal. Once the granulated mixture is fed into the die, the dosing stage is adjusted to achieve the dosing position. 
The granule is then locked between the punches (upper and lower) during precompression and main compression until ejection of the tablet is achieved. The precompression stage is very useful because it removes the air trapped in the die and reorganizes the packaging of particles. Likewise, the main compression stage compacts and, therefore, transforms the granulated powder bed into a tablet. Su, Q. et al. (2019).

\section{Results}

Table 2 shows the results of the drying experimentation by the lyophilization method. At the end of the drying process, an amount of avocado powder of $30-35 \%$ is obtained in relation to the avocado mass applied in the process. Ramos Solís, R. (2006).

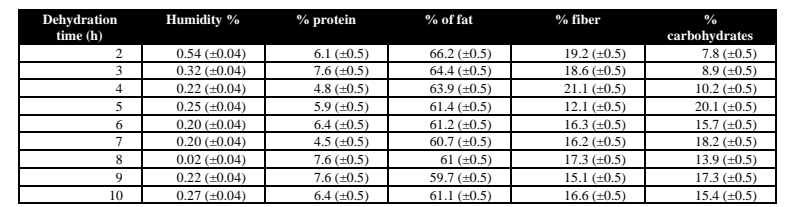

Table 2 Percentage of moisture based on dehydration time Source: Ramos Solís, R. (2006).

\section{Discussion of results}

Optimum dehydration times range from four to six hours, because after six hours of dehydration it would be necessary to apply less heat (less than $20^{\circ} \mathrm{C}$ ) to the containers and this would cause the product to become highly hygroscopic. In the same way, if dehydration is handled for one to three hours, it would cause damage to the nutritional and organoleptic properties of the avocado, since it would be necessary to apply more heat (greater than $35^{\circ} \mathrm{C}$ ) to the containers. Ramos Solís, R. (2006).

During the granulation process of avocado powder, a technique that can work with heat-sensitive materials is required, because the powder of this fruit requires specific temperature parameters $\left(20-35^{\circ} \mathrm{C}\right)$ in order not to lose its nutrients. For this reason, FBG and TSG would be the indicated granulation techniques to obtain successful avocado granules. On the one hand, FBG requires low energy requirements when drying the granules and this technique allows controlling the various operating parameters. However, this process requires more liquid solution to form successful granules which could result in wetter and therefore porous granules.
On the other hand, the granules formed by TSG present a higher load of the active principle of the drug, but the mechanism of this technique is difficult to control because any variation in the length, geometry and diameter of the screw could affect the properties of the granules. Therefore, FBG would be the most suitable technique to achieve successful avocado granules, as this process allows control of spray speed, fluidization speed, nozzle position and atomizing air pressure. Likewise, the use of more binder liquid in FBG would not be a key factor in the formation of avocado granules, because dehydrated avocado has very low moisture percentages.

On the other hand, the most indicated binder to use in FBG would be Povidone, since this binder can be used with water, hydroalcoholic solvents and pure polar organic solvents. Using PVP during FBG would be excellent, as this binder features ultra-low viscosity grades and allows high solution concentrations $(20 \%)$ during the process. Finally, in this study the solid avocado pills would be rectangular in shape due to the design of the rotary tablet press.

\section{Conclusions}

In this study, the manufacture of solid avocado pills has been proposed so that the nutrients of this fruit reach all sectors of the world. However, the substitution of the powder of the active ingredient of the medicine for the dehydrated powder of the avocado (in pharmaceutical processes) could present a great challenge for the manufacturers of these pills, due to all the variables and parameters that must be considered to achieve pills. solid successful. For this reason, in this study the use of FBG has been proposed to achieve the correct agglomeration of the avocado powder, because this technique would not alter the final properties of the avocado granules by being able to control the process parameters. Also, the use of Povidone during FBG was proposed, since the properties of this binder are compatible with FBG and, therefore, the use of PVP would allow the obtaining of successful avocado granules during granulation. On the other hand, in this study the use of a rotary tablet press (Natoli BLP-16) has been proposed to obtain solid avocado tablets. However, the avocado granules could be compacted with different compaction presses, for example the TDP 5 tablet press. 
This study is consistent with the article "The granulation process: practical experiences" by Capdevila, J. (1993), since granulation allows improving the hygienic quality of the food, less separation of ingredients during the process and easier for the storage and transport of agglomerates. However, this technique has high production costs and, based on the latest poverty measurement in Mexico prepared by Coneval (2018), 52.4 million poor people were registered. Therefore, food granulation as a sustainable and survival means could be a challenge in Mexico. Capdevila, J. (1993) and Lozano, L. (2019).

\section{References}

Arndt, O. R., Baggio, R., Adam, A. K., Harting, J., Franceschinis, E., \& Kleinebudde, P. (2018). Impact of Different Dry and Wet Granulation Techniques on Granule and Tablet Properties: A Comparative Study. Journal of Pharmaceutical Sciences, 107(12), 3143-3152. https://doi.org/10.1016/j.xphs.2018.09.006

Askarishahi, M., Maus, M., Schröder, D., Slade, D., Martinetz, M., \& Jajcevic, D. (2019). Mechanistic Modelling of Fluid Bed Granulation, Part I: Agglomeration in Pilot Scale Process. International Journal of Pharmaceutics, 118837.

https://doi.org/10.1016/j.ijpharm.2019.118837

Barría, C. (2019). Por qué se ha disparado el precio del aguacate y hasta cuándo seguirá subiendo - BBC News Mundo. (7 de agosto del 2019). Recuperado de https:// www.bbc.com/mundo/noticias-49209380

Calorías del aguacate: valor energético en $100 \mathrm{~g}$ y hoja nutricional. (21 de mayo del 2019). Recuperado

de https://www.ohmirevista.com/nutricion/calorias -del-aguacate-valor-energetico-en-100-g-yhoja-nutricional_art10790.html

Capdevila, J. (1993). El proceso de granulación: experiencias prácticas. IX Curso de especialización FEDNA.

Dürig, T., \& Karan, K. (2019). Binders in Wet Granulation. In Handbook of Pharmaceutical Wet Granulation. https://doi.org/10.1016/b9780-12-810460-6.00010-5
Hernández, R, Fernández, C, \& Baptista, P. (2010.). Metodología de la Investigación. México D.F.: Mc Graw Hill. p.p.1-275.

Lozano, L. (2019). Mucho combate a la pobreza, pero en México 4 de cada 5 la padecen. (17 de octubre 2019). Recuperado de https://www.forbes.com.mx/mexico-un-paiscon-52-4-millones-de-pobres-y-9-3-millonesen-pobreza-extrema/

Mulot, V., Benkhelifa, H., Pathier, D., Ndoye, F.-T., \& Flick, D. (2019). Experimental and numerical characterization of food dehydration during freezing. Journal of Food Engineering. https://doi:10.1016/j.jfoodeng.201 9.05.009

Organización de las Naciones Unidas [ONU]. (s.f.). Recuperado de https://www.un.org/sustainabledevelopment/es/ hunger/

PROFECO. (2019). profeco.gob.mx

Ramos Solís, R. (2006). Proceso para la obtencion de aguacate en polvo. https://patents.google.com/patent/ES2438623B $1 /$ es?q=aguacate\&oq=aguacate

Sostenibilidad. (s.f.). Recuperado de https://www.sostenibilidad.com/desarrollosostenible/la-sostenibilidad-del-sistemaalimentario/

Su, Q., Ganesh, S., Moreno, M., Bommireddy, Y., Gonzalez, M., Reklaitis, G. V., \& Nagy, Z. K. (2019). A perspective on Quality-by-Control (QbC) in pharmaceutical continuous manufacturing. Computers \& Chemical Engineering. https://doi:10.1016/j.compchemen g.2019.03.001

Suresh, P., Sreedhar, I., Vaidhiswaran, R., \& Venugopal, A. (2017). A comprehensive review on process and engineering aspects of pharmaceutical wet granulation. Chemical Engineering Journal, 328, 785815. https://doi:10.1016/j.cej.2017.07.091

Thapa, P., Tripathi, J., \& Jeong, S. H. (2019). Recent trends and future perspective of pharmaceutical wet granulation for better process understanding and product development. Powder Technology, 344, 864882. 
https://doi.org/10.1016/j.powtec.2018.12.080

Wang, L. G., Pradhan, S. U., Wassgren, C., Barrasso, D., Slade, D., \& Litster, J. D. (2020). A breakage kernel for use in population balance modelling of twin screw granulation. Powder Technology. https://doi:10.1016/j.powtec.2020. 01.024

Yeager, J. D., Dubey, M., Wolverton, M. J., Jablin, M. S., Majewski, J., Bahr, D. F., \& Hooks, D. E. (2011). Examining chemical structure at the interface between a polymer binder and a pharmaceutical crystal with neutron reflectometry. Polymer, 52(17), 3762-3768. https://doi.org/10.1016/j.polymer.2011.06.031. 